Pierre A. Casthely MD, James E. Cottrell MD, Patrice A. Urquhart CRNA

\title{
Comparison of metaproterenol, isoetharine and salbutamol in the relief of metha- choline-induced bronchospasm in dogs
}

We evaluated cardiovascular effects and effectiveness of isoetharine, metaproterenol and salbutamol, when administered intratracheally to relieve methacholine-induced bronchospasm in dogs anaesthetized with 50 per cent nitrous oxide, oxygen, halothane and mechanically ventilated. Methacholine $2 \mu \mathrm{g} \cdot \mathrm{kg}^{-1}$. hour ${ }^{-1}$ was administrated first followed by halothane (IMAC) for 30 minutes (control), then metaproterenal, isoetharine or sulbutamol. Metaproterenol (15 $\mathrm{mg}$ ) significantly decreased transpulmonary pressure to $20.1 \pm 0.5$ (SE) from $22.5 \pm 1.15 \mathrm{cmH}_{2} \mathrm{O}(p<0.025)$ after three min and to $15 \pm 0.5 \mathrm{cmH}_{2} \mathrm{O}(p<0.005)$ after $90 \mathrm{~min}$. Isoetharine $(2.5 \mathrm{mg})$ decreased transpulmonary pressure after five $\min$ to $22.1 \pm 1$ from $24.5 \pm 1.5 \mathrm{cmH}_{2} \mathrm{O}(\mathrm{p}<0.05)$, and to $21.75 \pm 0.55 \mathrm{mmH}_{2} \mathrm{O}$ after $90 \mathrm{~min}$. Salbutamol 25 $\mu \mathrm{g} \cdot \mathrm{kg}^{-1}$ decreased transpulmonary pressure to $20.7 \pm$ 0.75 from $24.25 \pm 1.28$ after three min and to $16 \pm .5$ after $90 \mathrm{~min}$.

The peak effects on airway pressure occurred at $15 \mathrm{~min}$ for metaproterenol, 25 min for salbutamol and 20 min for isoetharine. Pulmonary vascular resistance was not significantly changed during halothane anaesthesia

From the Department of Anaesthesiology, State University Hospital, Downstate Medical Center, Brooklyn, New York.

Address correspondence 10: Dr. Pierre A. Casthely, Department of Anesthesiology, State University Hospital, Downstate Medical Center, 450 Clarkson Avenue, Brooklyn, New York 11203. alone but decreased significantly after metaproterenol and isoetharine infusion. Heart rate increased ten per cent after metaproterenol, three per cent after isoetharine, and five per cent after salbutamol. No arrhyth. mias occurred in any group. Cardiac output increased significantly to $3.25 \pm 0.2$ from $1.5 \pm 0.17 \mathrm{~L} \cdot \mathrm{min}^{-1}$ $(p<0.025)$ after metaproterenol to $3.2 \pm .025$ from $1.45 \pm .009$ after salbutamol and was unchanged after isoetharine.

Metaproterenol and salbutamol in the presence of I MAC halothane anaesthesia relieved methacholine-induced bronchospasm more rapidly than did isoetharine. The onset of effect was $3 \pm 0.05$ min for metaproterenol and salbutamol and $5 \pm 0.01 \mathrm{~min}$ for isoetharine. The effect lasted $210 \pm 10.5 \mathrm{~min}$ for metaproterenol, $170 \pm$ $12.5 \mathrm{~min}$ for salbutamol and $90 \pm 4.75 \mathrm{~min}$ for isoetharine.

\section{Key words}

LUNG: bronchospasm; BRONCHODILATORS: metaproterenol, isoetharine, methacholine.

Patients with a history of bronchospastic disease requiring surgery are at risk because of the likelihood of precipitation of severe bronchospasm. Halothane and enflurane have been shown to attenuate antigen induced bronchospasm produced in an isolated lobe of the dog lung. ${ }^{1,2}$ Halothane had a greater effect at equivalent MAC levels and thus has been suggested as the anaesthetic of choice for 
asthmatic patients. However, halothane sensitized the myocardium to catecholamines, and arrhythmias have been reported after its use. ${ }^{3}$ Furthermore, when halothane is combined with aminophylline the hazard of arrhythmias is increased, even in the presence of normocarbia. ${ }^{4}$ Administration of a metered dose of nebulized isoproterenol to the anaesthetized patient with bronchospasm is frequently a useful therapeutic measure. However, its use is also hazardous because of potential tachyarrhythmias that result from the systemic absorption of the medication. Metaproterenol administered as a microaerosol has been found to improve pulmonary function in patients with bronchospastic diseases. It has not been associated with dangerous side effects. ${ }^{5,6}$ Isoetharine also has been used increasingly in aerosol form intraoperatively, during the postoperative period, and in intensive care units to produce bronchodilation. ${ }^{7}$ Salbutamol is a

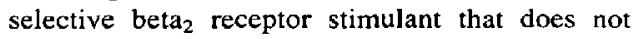
cause tachycardia in man when effective doses are taken by aerosol or orally. ${ }^{8}$ Because of these reported advantages we decided to compare the effectiveness of metaproterenol, isoetharine and salbutamol in reducing methacholine-induced bronchospasm in dogs during halothane anaesthesia.

\section{Methods}

Anaesthesia was induced in 12 mongrel dogs weighing $18-24 \mathrm{~kg}$ with sodium pentobarbitone $10 \mathrm{mg} \cdot \mathrm{kg}^{-1}$ followed by tracheal intubation with a \# 10 Lanz endotracheal tube. The dogs were then ventilated using a Drager ventilator with a tidal volume of $20 \mathrm{ml} \cdot \mathrm{kg}^{-1}$, at a rate of $10 /$ minute. Anaesthesia was maintained with 50 per cent $\mathrm{N}_{2} \mathrm{O}$ and $\mathrm{O}_{2}$. The electrocardiogram (EKG) was continuously monitored via leads II and V5.

A \#7 French Swan-Ganz catheter was inserted through the femoral vein into the pulmonary artery for measurement of cardiac output and central venous pressure (CVP) and pulmonary artery pressure (PAP) monitoring. The femoral artery was also cannulated for arterial pressure monitoring and blood gas sampling. End-tidal $\mathrm{CO}_{2}$ was monitored using a Beckman $\mathrm{CO}_{2}$ analyzer with an electronic digital readout. Expired tidal volume was measured using a Drager volumeter placed on the expiratory limb of the anaesthesia circuit. Compliance was calculated using the formula: compliance $=$ expiratory tidal volume/peak pressure at end inspiration
- end expiratory airway pressure. Intrapleural pressure was monitored using an oesophageal balloon connected to a transducer and attached to a Hewlett Packard channel recorder. Transpulmonary pressure was calculated by subtracting the airway pressure from the intrapleural pressure. The resistive component was subtracted from total transpulmonary pressure by taking readings at times of zero flow (beginning and end of inspiration). Airway pressure was monitored through a 21 gauge needle inserted into the tracheal tube and connected via transducer to the recorder. Bronchoconstriction was induced, after placement of monitors and after anaesthetic induction, with a continuous infusion of methacholine at a rate sufficient to increase the airway pressure to 2.5 times the control value.

This dosage was determined by infusing methacholine in six control dogs (not included in the study) in which the effect on airway pressure did not increase in magnitude over a four-hour period. The amount of methacholine required was $2.0 \pm 0.02$ $\mu \mathrm{g} \cdot \mathrm{kg}^{-1} \cdot \mathrm{h}^{-1}$. After a 30 -minute stabilization period following methacholine administration, halothane $1 \mathrm{MAC}$ was administered for 30 minutes and all the data obtained at that point were used as the control values to examine the efficacy of the bronchodilators. Metaproterenol $0.75 \mathrm{mg} \cdot \mathrm{kg}^{-1}$ or isoetharine $0.125 \mathrm{mg} \cdot \mathrm{kg}^{-1}$ or salbutamol $25 \mu \mathrm{g} \cdot \mathrm{kg}^{-1}$ diluted with $2 \mathrm{ml}$ normal saline were then directly injected trans-tracheally with a 25 gauge needle puncture through a small incision performed at the anterior part of the trachea distal to the end of the endotracheal tube. Arterial blood gas tensions (ABG), alveolar-arterial oxygen tension differences (A-a) $\mathrm{DO}_{2}$, transpulmonary pressure, and pulmonary compliance was calculated 30 minutes before and after methacholine infusion, 30 minutes after halothane administration, and 5,15 , and 30 minutes, 1 hour, 2 hours, and 4 hours after injection of bronchodilators. Pulmonary vascular resistance (PVR) was calculated using the formula:

$P V R=\frac{P A-P C W P}{C O} \times 79.9$,

where

$\mathrm{PA}=$ mean pulmonary artery pressure,

PCWP = pulmonary capillary wedge pressure,

$\mathrm{CO}=$ cardiac output. 
Statistical analysis within each group was done using Student's t test for paired data and the results expressed as mean \pm standard error. A $p$ value of $<0.05$ was considered significant.

Statistical analysis between the different groups was performed using the multiple range test (modified LSD procedure). ${ }^{9}$

\section{Results}

The administration of halothane for 30 minutes had only a slight effect on transpulmonary pressure during continuous methacholine infusion. In contrast, when combined with administration of metaproterenol there was a significant decrease in transpulmonary pressure to $20.1 \pm 0.5$ from $22.5 \pm$ $1.15 \mathrm{cmH}_{2} \mathrm{O}(\mathrm{p}<0.025)$ after three minutes and to $15 \pm 0.5 \mathrm{cmH}_{2} \mathrm{O}(p<0.005)$ after 90 minutes.

When isoetharine was administrated with halothane, the transpulmonary pressure significantly decreased after five minutes to $22.1 \pm 1$ from $24.5 \pm 1.5 \mathrm{cmH}_{2} \mathrm{O}(\mathrm{p}<0.05)$ to $21.75 \pm 0.55$ $\mathrm{cmH}_{2} \mathrm{O}$ after 90 minutes. Administration of salbutamol resulted in decrease of transpulmonary pressure to $20.7 \pm 0.75$ after three minutes from $24.25 \pm 1.25$ and to $16 \pm 0.5$ after 90 minutes.

Pulmonary vascular resistance was unaffected by $1 \mathrm{MAC}$ of halothane but decreased significantly after administration of metaproterenol, isoetharine, and salbutamol. Metaproterenol had the greater effect and the longest duration of action (Table I).

Heart rate increased 15 per cent after salbutamol, ten per cent after metaproterenol $(p<0.025)$ but increased only three per cent after isoetharine $(\mathrm{p}<0.10)$. No significant arrhythmias occurred in any group. Mean arterial pressure was unchanged after isoetharine but increased significantly to 110 \pm 10.5 from $80 \pm 8.5 \mathrm{mmHg}(p<0.025)$ after metaproterenol and to $115 \pm 11$ from $80.5 \pm 8.5$ $\mathrm{mmHg}$ after salbutamol.

Halothane anaesthesia was associated with an insignificant increase in (A-a) $\mathrm{DO}_{2}$. Following metaproterenol, isoetharine and salbutamol, $(A-a) \mathrm{DO}_{2}$ further increased to $275 \pm 15$ from $180 \pm 15.5$ $\mathrm{mmHg}(\mathrm{p}<0.005)$ and to $195 \pm 20.75$ from $165 \pm$ $15 \mathrm{mmHg}$ ( $p<0.02$ ), to $255 \pm 18.75$ from $170.5 \pm$ 15 respectively. Cardiac output increased to $3.25 \pm$ 0.02 from $1.5 \pm 0.017 \mathrm{~L} \cdot \mathrm{min}^{-1} 60$ minutes after metaproterenol and to $1.90 \pm 0.02$ from $1.25 \pm$ $.012 \mathrm{~L} \cdot \mathrm{min}^{-1} 60$ minutes after isoetharine, and to
$3.2 \pm .025$ from $1.45 \pm 0.009 \mathrm{~L} \cdot \mathrm{min}^{-1}$ after salbutamol.

After metaproterenol, compliance increased to $75 \pm 16 \mathrm{~L} / \mathrm{cmH}_{2} \mathrm{O}$ three minutes from $14 \pm$ $3 \mathrm{~L} / \mathrm{cmH}_{2} \mathrm{O}, 105 \pm 16.5$ after five minutes, and $145 \pm 20$ after 90 minutes.

Isoetharine increased the compliance to $25 \pm 7.5$ from $15 \pm 1.8 \mathrm{~L} / \mathrm{cmH}_{2} \mathrm{O}$ after three minutes, $70 \pm$ 10 after five minutes, and $105 \pm 15$ after 90 minutes.

Salbutamol increased compliance to $60 \pm$ $6 \mathrm{~L} / \mathrm{cmH}_{2} \mathrm{O}$ from $16 \pm 1.2$ after three minutes, to $90 \pm 13.5$ after five minutes, and $127 \pm 12.5$ after 90 minutes. The peak effect on airway pressure occurred at 15 minutes for metaproterenol, 20 minutes after isoetharine and 25 minutes after salbutamol. The duration of action was 210 minutes for metaproterenol, 90 minutes for isoetharine and 170 minutes for salbutamol.

\section{Discussion}

It is widely believed that halothane is a bronchodilator and that bronchospasm during anaesthesia may be relieved by increasing the inspired halothane concentration. Shnider and Papper recommended the use of halothane in the asthmatic patient. ${ }^{10}$ The studies of Hirshman and Bergman in which induced bronchoconstriction was reversed by halothane and influrane also support this concept. ${ }^{1}$

In our studies $1 \mathrm{MAC}$ halothane anaesthesia for 30 minutes did not produce a significant decrease of peripheral vascular resistance or transpulmonary pressure. This does not mean that halothane is not an effective bronchodilator, as previously reported. The purpose of our study was not to evaluate the effect of halothane on bronchomotor tone. This model may not be representative of the asthmatic with atopic bronchospasm. Perhaps more than 1 MAC of halothane would have been needed to produce a noticeable effect in this model.

Metaproterenol is a resorcinol compound $(1,3,5$ dihydroxyphenyl-2-isopropyl-amino-ethanol-sulfate) and, unlike the catecholamines, is not degraded by catechol-o-methyltransferase (COMT) because of the presence of a dihydroxy group. ${ }^{11,12}$ Salbutamol, a 2-t-butylamino-1-(4-hydroxy, 3-hydroxymethy/phenylethanol is a non catechol adrenergic beta stimulant which is also not a substrate for 
TABLE 1 Cardiorespiratory data (mean \pm SE)

\begin{tabular}{|c|c|c|c|c|}
\hline & Group & $\begin{array}{l}\text { Before } \\
\text { methacholine }\end{array}$ & $\begin{array}{l}\text { After } \\
\text { methacholine }\end{array}$ & $\begin{array}{l}\text { Control } \\
30 \text { minutes } \\
\text { after halothane }\end{array}$ \\
\hline Aa- $\mathrm{DO}_{2}(\mathrm{mmHg})$ & $\begin{array}{l}\mathrm{M} \\
\mathrm{I} \\
\mathrm{S}\end{array}$ & $\begin{array}{r}65 \pm 10.5 \\
62 \pm 11.2 \\
67.5 \pm 9.75\end{array}$ & $\begin{array}{l}175 \pm 15^{*} \\
163 \pm 20^{*} \\
169 \pm 17^{*}\end{array}$ & $\begin{aligned} 180 & \pm 15.5 \\
165 & \pm 19.5 \\
170.5 & \pm 15\end{aligned}$ \\
\hline $\begin{array}{l}\text { Transpulmonary } \\
\text { pressure } \\
\left(\mathrm{cmH}_{2} \mathrm{O}\right)\end{array}$ & $\begin{array}{l}\mathrm{M} \\
\mathrm{I} \\
\mathrm{S}\end{array}$ & $\begin{array}{c}9.5 \pm .5 \\
10 \pm 1.2 \\
11.5 \pm 1\end{array}$ & $\begin{aligned} 25 & =1.5^{*} \\
25 & =1.2^{*} \\
26.5 & =1.0^{*}\end{aligned}$ & $\begin{array}{c}22.5 \pm 1.15 \\
24.5 \pm 1.5 \\
24.25 \pm 1.25\end{array}$ \\
\hline $\begin{array}{l}\text { Pulmonary art } \\
\text { pressure (mmHg) }\end{array}$ & $\begin{array}{l}\mathrm{M} \\
\mathrm{I} \\
\mathrm{S}\end{array}$ & $\begin{array}{l}8.5 \pm 1 \\
8.75 \pm 1.15 \\
9.10 \pm 1.5\end{array}$ & $\begin{aligned} 20 & \pm 3.5^{*} \\
29.5 & =2.5^{*} \\
25 & \pm 2.0^{*}\end{aligned}$ & $\begin{array}{l}19.85 \pm 3 \\
19.75 \pm 2.5 \\
23.5 \pm 1.9\end{array}$ \\
\hline $\begin{array}{l}\text { Mean blood } \\
\text { pressure }(\mathrm{mmHg})\end{array}$ & $\begin{array}{l}\mathrm{M} \\
\mathrm{I} \\
\mathrm{S}\end{array}$ & $\begin{aligned} 85 & \pm 8.5 \\
90 & \pm 9 \\
87.5 & \pm 8.5\end{aligned}$ & $\begin{array}{l}95 \pm 9.0 \\
97 \pm 9.25 \\
92 \pm 8.5\end{array}$ & $\begin{aligned} 80 & \pm 8.5 \\
85 & \pm 8 \\
80.5 & \pm 8.5\end{aligned}$ \\
\hline $\begin{array}{l}\text { Heart rate } \\
\text { (beats/min) }\end{array}$ & $\begin{array}{l}\mathrm{M} \\
\mathrm{I} \\
\mathrm{S}\end{array}$ & $\begin{array}{c}128 \pm 10 \\
125 \pm 9.5 \\
127.5 \pm 9.75\end{array}$ & $\begin{array}{l}125 \pm 10.5 \\
110 \pm 10.0 \\
120 \pm 15.0\end{array}$ & $\begin{array}{l}110 \pm 11 \\
115 \pm 11 \\
110 \pm 10.5\end{array}$ \\
\hline $\begin{array}{l}\text { Cardiac output } \\
\left(\mathrm{L} \cdot \mathrm{min}^{-1}\right)\end{array}$ & $\begin{array}{l}\mathrm{M} \\
\mathrm{I} \\
\mathrm{S}\end{array}$ & $\begin{array}{l}2.5 \pm .05 \\
2.3 \pm .04 \\
2.4 \pm .05\end{array}$ & $\begin{array}{l}1.75=.015^{*} \\
1.50=.015^{*} \\
1.65 \pm .010^{*}\end{array}$ & $\begin{array}{r}1.5 \pm .017 \\
1.25 \pm .012 \\
1.45 \pm .009\end{array}$ \\
\hline $\begin{array}{l}\text { PVR } \\
\text { (dynes } \cdot \mathrm{sec} \cdot \mathrm{cm}^{-5} \text { ) }\end{array}$ & $\begin{array}{l}\mathrm{M} \\
\mathrm{I} \\
\mathrm{S}\end{array}$ & $\begin{array}{l}48 \pm 10 \\
49 \pm 10.5 \\
50 \pm 11.25\end{array}$ & $\begin{array}{l}379 \pm 45^{*} \\
415 \pm 40.5^{*} \\
365 \pm 35^{*}\end{array}$ & $\begin{array}{l}365 \pm 45.5 \\
405 \pm 49 \\
359 \pm 36.5\end{array}$ \\
\hline $\begin{array}{l}\text { Compliance } \\
\left(\mathrm{L} / \mathrm{cmH}_{2} \mathrm{O}\right)\end{array}$ & $\begin{array}{l}M \\
I \\
S\end{array}$ & $\begin{array}{l}180 \pm 30.5 \\
175 \pm 25 \\
185 \pm 22\end{array}$ & $\begin{aligned} 11 & \pm 3.5^{*} \\
10.5 & \pm 1.75^{*} \\
12.5 & =1^{*}\end{aligned}$ & $\begin{array}{l}14 \pm 3 \\
15 \pm 1.8 \\
16 \pm 1.2\end{array}$ \\
\hline
\end{tabular}

$* \mathrm{p}<0.05$

$\mathrm{M}=$ Metaproterenol; $\mathrm{I}=$ Isoetharine; $\mathrm{S}=$ Salbutamol

catechol-o-methyltransferase. ${ }^{13}$ Isoetharine has the same basic nucleus as the catecholamines, except for an ethyl group on the alpha carbon adjacent to the terminal nitrogen, which makes it easier to be degraded by COMT. That may be one reason why metaproterenol and salbutamol has a much longer duration of action than isoetharine ( 210 minutes for metaproterenol, 170 minutes for salbutamol and 90 minutes for isoetharine). In addition metaproterenol and salbutamol acted faster than isoetharine, their onset of action being three and five minutes respectively. These characteristics are also noted clinically. ${ }^{12,14,15}$ Minimal cardiovascular effects occurred during metaproterenol, salbutamol and isoetharine administration in the presence of halothane.

Cardiac output, which increased significantly after metaproterenol and salbutamol, was unchanged with isoetharine. This may be explained by the greater beta stimulating action of metaproterenol and salbutamol absorbed from the tracheobronchial tree. In addition bronchodilation corrects the respiratory acidosis and protects against the deleterious effect of acidosis on the myocardium. Acidosis depresses the myocardium by altering the calcium cycle and by decreasing myocardial responsiveness to catecholamines. Heart rate increased more after metaproterenol and salbutamol than after isoetharine. The increase in heart rate caused by those drugs was probably due to reflexes secondary to beta mediated peripheral vasodilation and to some minimal beta $a_{1}$ effect.

When these drugs were used in combination with halothane, the incidence of arrhythmias were minimal, making them particularly suitable for the treatment of bronchospasm during anaesthesia. Hypotension as previously reported following 
TABLE II Cardiorespiratory data (mean \pm SE) after metaproterenol, jsoetharine, or salbutamol administration

\begin{tabular}{|c|c|c|c|c|c|}
\hline & \multirow[b]{2}{*}{ Group } & \multicolumn{4}{|c|}{ Minutes after Medications* } \\
\hline & & 3 & 5 & 90 & 140 \\
\hline $\begin{array}{l}\mathrm{Aa}-\mathrm{DO}_{2} \\
(\mathrm{mmHg})\end{array}$ & $\begin{array}{l}\mathrm{M} \\
\mathrm{I} \\
\mathrm{S}\end{array}$ & $\begin{array}{l}195 \pm 16.5 \\
170 \pm 19 \\
180 \pm 16\end{array}$ & $\begin{array}{l}225 \pm 16.75 \dagger \ddagger \\
18.5 \pm 19.5 \\
230 \pm 20.5\end{array}$ & $\begin{array}{l}275 \pm 15 \\
165 \pm 15 \\
255 \pm 18.75\end{array}$ & $\begin{array}{l}170 \pm 14.5 \\
155 \pm 15 \\
160 \pm 12.75\end{array}$ \\
\hline $\begin{array}{l}\text { Transpulmonary } \\
\text { pressure } \\
\left(\mathrm{cmH}_{2} \mathrm{O}\right)\end{array}$ & $\begin{array}{l}\mathrm{M} \\
\mathrm{I} \\
\mathrm{S}\end{array}$ & $\begin{array}{l}20.1 \pm .5 \div \ddagger \\
23.1 \pm 1.15 \\
20.7 \pm .75\end{array}$ & $\begin{array}{l}19.5 \pm 60 \dagger \ddagger \\
22.1 \pm 1 \dagger \\
20 \pm 0.85\end{array}$ & $\begin{aligned} 15 & \pm 0.5 \dagger \ddagger \\
21.75 & \pm 0.55 \dagger \\
16 & \pm 0.5\end{aligned}$ & $\begin{aligned} 24.5 & \pm 1.5 \\
25 & \pm 1.55 \\
23.75 & \pm 1.5\end{aligned}$ \\
\hline $\begin{array}{l}\text { Pul. art. } \\
\text { pressure } \\
(\mathrm{mmHg})\end{array}$ & $\begin{array}{l}\mathrm{M} \\
\mathrm{I} \\
\mathrm{S}\end{array}$ & $\begin{array}{l}16.5 \pm 1.2 \\
18.5 \pm 2 \\
17 \pm 1.7\end{array}$ & $\begin{aligned} 14 & \pm 1 \dagger \\
16.5 & \pm 1.5 \\
15 & \pm 1.5\end{aligned}$ & $\begin{aligned} 10.5 & \pm 0.95 \dagger \\
16 & \pm 1.25 \dagger \\
11 & \pm 1\end{aligned}$ & $\begin{array}{c}18.5 \pm 2.5 \\
19 \pm 3 \\
19 \pm 2.0\end{array}$ \\
\hline $\begin{array}{l}\text { Mean blood } \\
\text { pressure } \\
(\mathrm{mmHg})\end{array}$ & $\begin{array}{l}\mathrm{M} \\
1 \\
\mathrm{~S}\end{array}$ & $\begin{array}{l}110 \pm 10.5 \dagger \ddagger \\
90 \pm 9.5 \\
115 \pm 11\end{array}$ & $\begin{aligned} 115 & \pm 10.75 \dagger \ddagger \\
87.5 & \pm 8.5 \\
117.5 & \pm 10.9\end{aligned}$ & $\begin{aligned} 100 & \pm 10.5 \dagger \\
90 & \pm 8.5 \\
110 & \pm 10\end{aligned}$ & $\begin{aligned} & 90 \pm 10 \\
90.5 & \pm 8.75 \\
92.5 & \pm 9\end{aligned}$ \\
\hline $\begin{array}{l}\text { Heart rate } \\
\text { (beats/min) }\end{array}$ & $\begin{array}{l}\mathrm{M} \\
\mathrm{I} \\
\mathrm{S}\end{array}$ & $\begin{array}{l}125 \pm 10.5 \ddagger \\
119 \pm 12 \\
130 \pm 10.5\end{array}$ & $\begin{array}{l}130 \pm 9.5 t \ddagger \\
120 \pm 11.5 \\
138 \pm 13\end{array}$ & $\begin{array}{l}129 \pm 13 \\
117 \pm 12 \\
130 \pm 12.5\end{array}$ & $\begin{array}{r}125 \pm 10 \\
119 \pm 13 \\
127.5 \pm 15\end{array}$ \\
\hline $\begin{array}{l}\text { Cardiac Output } \\
\left(\mathrm{L} \cdot \mathrm{min}^{-1}\right)\end{array}$ & $\begin{array}{l}M \\
1 \\
S\end{array}$ & $\begin{array}{l}2.75 \pm .025 \dagger \ddagger \\
1.30 \pm .015 \\
2.5=.02\end{array}$ & $\begin{array}{l}3.25 \pm 0.20 \dagger \div \\
1.40 \pm 0.015 \\
3.2 \pm 0.025\end{array}$ & $\begin{array}{l}3.01 \pm 0.035 t \ddagger \\
1.90 \pm 0.020 \\
2.80 \pm 0.019\end{array}$ & $\begin{array}{r}2.05 \pm 0.02 \\
1.75 \pm 0.02 \\
2.1 \pm 0.02\end{array}$ \\
\hline $\begin{array}{l}\text { PVR } \\
\text { (dynes.sec } \cdot \mathrm{cm}^{-5} \text { ) }\end{array}$ & $\begin{array}{l}\mathrm{M} \\
\mathrm{I} \\
\mathrm{S}\end{array}$ & $\begin{array}{l}275=30.5 \\
395 \pm 45 \\
305 \pm 29.75\end{array}$ & $\begin{array}{l}205 \pm 20.5 \dagger \neq \\
305 \pm 40 \\
245 \pm 25\end{array}$ & $\begin{array}{c}150 \pm 15 t \ddagger \\
397 \pm 40 \\
197.5 \pm 20\end{array}$ & $\begin{array}{l}360 \pm 35 \\
399 \pm 40 \\
375 \pm 37.5\end{array}$ \\
\hline $\begin{array}{l}\text { Compliance } \\
\left(\mathrm{L} \cdot \mathrm{cmH}_{2} \mathrm{O}\right)\end{array}$ & $\begin{array}{l}\mathrm{M} \\
\mathrm{I} \\
\mathrm{S}\end{array}$ & $\begin{array}{l}75 \pm 16 \dagger \ddagger \\
25 \pm 7.5 \\
60 \pm 6\end{array}$ & $\begin{array}{c}105 \pm 16.5 \dagger \div \\
70 \pm 10 \dagger \\
90 \pm 13.5\end{array}$ & $\begin{array}{l}145 \pm 20 \dagger \neq \\
105 \pm 15 \dagger \\
127 \pm 12.5\end{array}$ & $\begin{array}{l}60 \pm 8.5 \\
20 \pm 5.5 \\
35 \pm 6.7\end{array}$ \\
\hline
\end{tabular}

*Bronchodilators administered during halothane anaesthesia and metacholine-induced bronchospasm.

†Statistical significance within each group $(p<0.05)$.

$¥$ Statistical significance between different groups $(p<0.05)$

$\mathrm{M}=$ Metaproterenol; I = Isoetharine; $\mathrm{S}=$ Salbutamol.

aminophylline administration was not seen after isoetharine, metaproterenol, or salbutamol. Mean blood pressure ws unchanged after isoetharine but increased significantly with metaproterenol and salbutamol.

The alveolar arterial oxygen tension difference increased significantly after the administration of all three bronchodilators. Hypoxic pulmonary vasoconstriction constitutes an autoregulatory mechanism by which the lung favourably adjusts ventilation perfusion ratios by diverting blood from hypoxic regions of the lung to areas more adequately ventilated. The two most important components of this reflex are pulmonary vascular resistance and blood flow. Hypoxic pulmonary vascoconstriction is well known to be inhibited by most of the bronchodilators. However it is not inhibited by aminophylline. ${ }^{16}$ We do not know the specific effects of isoetharine, metaproterenol and salbutamol on hypoxic pulmonary vasoconstriction. Bronchodilatation after administration of bronchodilators predominantly occurs in the large airways. ${ }^{17}$ Metaproterenol, isoetharine and salbutamol will have little effect on the small airways. Since they increase cardiac output and may inhibit hypoxic pulmonary vasoconstriction they will increase blood flow to the dependent parts of the lung, therefore increasing ventilation perfusion mismatch.

If a bronchodilator is needed during anaesthesia and surgery, salbutamol or metaproterenol are recommended over isoetharine because of more rapid onset, longer duration of action, and fewer adverse cardiovascular effects. 


\section{Acknowledgernents}

We thank Mr. George McCoy and Mrs. Miriam Stucker, Technical Specialists, for thcir valuable assistance in this research project, and Jack Chalon, M.D., Professor of Anesthesiology at New York University, for editorial assistance, and Ms. Ellen L. Jackson for manuscript preparation.

\section{References}

1 Hirshman CA, Bergman NA. Anesthetic reversal of bronchoconstriction in an asthma dog mode. Anesth Analg 1978; 57: 629-33.

2 Brakensiek AL, Bergman NA. The effects of halothane and atropine on total respiratory resistance in anesthetized man. Anesthesiology 1970; 33:341-47.

3 Hall $K D$, Norris FH. Fluothane sensitization of dog heart to action of epinephrine. Anesthesiology 1958; 19: 631-37.

4 Stirt JA, Berger JM, Roe SD, Ricker SM, Sullivan $S F$. Halothane-induced cardiac arrhythmias following administration of aminophylline in experimental animals. Anesth Analg 1981; 60: 517-20.

5 Swartz CL, Hyde JS. Long term efficacy and safety or nebulized metaproterenol solution in bronchial asthma. Chest 1976; 70: 617-20.

6 Beck GJ. Controlled clinical trial of a new dosage form of metaproterenol. Ann Allergy 1980;44: 19-22.

7 Sprague DH. Treatment of intraoperative bronchospasm with nebulized isoetharine. Anesthesiology 1977; 46: 222-24.

8 Kennedy MCS, Simpson WT. Human pharmacological and clinical studics on salbutamol: a specific betaadrenergic bronchodilator. Br J Dis Chest 1969; 63: 165-74.

9 Duncan $D B$. On the properties of the multiple comparisons test. Virginia J Sci 1952; 3: 49-67.

10 Shnider SM, Papper EM. Anesthesia for the asthmatic patient. Anesthesiology 1961; 22: 886-92.

11 Chervinsky $P$. Sixty day trial of a new inhalant dosage form of meta-proterenol. Ann Allergy 1977; 38: 107-11.

12 Hurst A. Metaproterenol: A potent and safe broncho dilator. Ann Allergy 1973; 31: 460-65.

13 Walker SR, Evans ME, Richards AJ, Paterson JW. The clinical pharmacology of oral and inhaled salbutamol. Clin Pharmacol Ther 1972; 13: 861-67.

14 Emirgil C, Dwyer K, Sobol BJ. A comparison of the duration of action and the cardiovascular effects of metaproterenol and an isoetharine phenylephrine combination. Curr Ther Res 1976; 19: 371-78.

15 Holmes $T H$. A comparative clinical trial of metaproterenol and isoproterenol as bronchodilator aerosols. Clin Pharmacol Ther 1968; 9: 617-24.

16 Benumoff $J$, Trousdale $F$. Aminophylline does not inhibit hypoxic pulmonary vasoconstriction. Anesthesiology 1982; 57: A470.

17 Larson CP Jr, Severinghaus JW. Postural variations in deadspace and $\mathrm{CO}_{2}$ gradients breathing air and oxygen. J Appl Physiol 1972; 17: 417-20.

\section{Résumé}

Les effets cardiovasculaires et l'efficacité de l'isoetharine, métaprotérénol et salbutamol lors de l'administration intratrachéale afin de corriger le bronchospasme induit par la méthacholine chez les chiens anesthésiés avec 50 pour cent de protoxyde d'azoteloxygène/halothane et ventilés mécaniquement, ont été évalués. La méthacholine $2 \mu \mathrm{g} \cdot \mathrm{kg}^{-1} \cdot$ heure $^{-1}$ a été administrée initialement, suivie par l'administration de I MAC d'halothane pour 30 minutes (controle) puis l'administration de métaprotérénol, isoetharine ou salbutamol. L'administration d'halothane (1 MAC) avant l'administration des bronchodilatateurs a diminué légèrement la pression des voies aériennes. L'administration de métaprotérénol (15 mg) a diminué significativement la pression trans-pulmonaire a $20.1 \pm 0.5$ (SE) de $22.5 \pm 1.15 \mathrm{~cm} \mathrm{H} \mathrm{H}_{2} \mathrm{O}$ $(p<0.025)$ après trois minutes et à $15 \pm 0.5 \mathrm{cmH}_{2} \mathrm{O}$ $(p<0.005)$ après 90 minutes pour une durée totale de 110 minutes. L'isoetharine (2.5 mg) a diminué la pression trans-pulmonaire après cinq 5 minutes à $22 . I \pm 1$ de $24.5 \pm 1.5 \mathrm{cmH}_{2} \mathrm{O}(p<0.05)$, et à $21.75 \pm 0.55 \mathrm{mmH}_{2} \mathrm{O}$ après 90 minutes. Le salbutamol $25 \mu \mathrm{g} \cdot \mathrm{kg}^{-1}$ a diminué la pression trans-pulmonaire à $20.7 \pm 0.75$ de $24.25 \pm$ 1.28 après trois minutes et à $16 \pm 0.5$ après 90 minutes pour une durée totale de 160 minutes.

Le maximum d'effet du métaprotérénol sur les voies aériennes survient à 15 minuses et à 25 minutes pour le salbutamol et 20 minutes pour l'isoetharine. La résistance vasculaire pulmonaire n'érait pas significativement perturbee lors de l'administration de 1 MAC d'halothane mais a diminué significativement après métaprotérénol et la perfusion d'isoetharine. La fréquence cardiaque augmenta de dix pour cent après métaprotérénol, trois pour cent après isoetharine et cinq pour cent après salbutamol. Aucune arythmie n'est survenue dans les trois groupes. Le débit cardiaque 
augmenta significativement à $3.24 \pm 0.2$ de $1.5 \pm 0.17$ litresimin. $(p<0.025)$ après métaprotérénol à $3.2 \pm$ .025 de $1.45 \pm .009$ et n' était pas statistiquement changé après isoetharine.

La métaprotérénol et le salbutamol en présence de 1 MAC d'halothane soulagent le bronchospasme induit par la méthacholine plus rapidement que l'isoetharine. Le début de l'effet était de $3 \pm 0.05 \mathrm{~min}$. pour le métaprotérénol et salbutamol et $5 \pm 0.01 \mathrm{~min}$. pour l'isoetharine. L'effet a duré $(210 \pm 10.5$ min pour le métaprotérénol, $170 \pm 12.5$ pour le salbutamol et $90 \pm 4.75 \mathrm{~min}$ pour l'isoetharine). 